\title{
Fairy Tale Telling Effects People with Dementia
}

\author{
Ingrid Kollak
}

University of Applied Sciences, Berlin, Germany

*Corresponding author: Ingrid Kollak, University of Applied Sciences, Berlin, Germany, Tel: 030 99245409; Fax: 030 99245245; E-mail: kollak@ash-berlin.eu Received: August 08, 2016, Accepted: September 19, 2016; Published: September 26, 2016

Copyright: () 2016 Kollak I. This is an open-access article distributed under the terms of the Creative Commons Attribution License, which permits unrestricted use, distribution, and reproduction in any medium, provided the original author and source are credited.

Citation: Kollak I (2016) Fairy Tale Telling Effects People with Dementia. J Gen Pract (Los Angel) 4: 268. doit 0.4172/2329-9126.1000268

\section{Commentary}

How do residents of nursing homes who suffer from dementia and display challenging behavior react to fairy tale narrations? (How) can fairy tale narrations improve the residents' quality of life and support caring routines?

The Study examines these questions by evaluating the project, "Once upon a time... Fairy tales and dementia". The project offers fairy tale narrations in five nursing homes (Berlin, Frankfurt/M. and Stade), which are organized by Märchenland - Deutsches Zentrum für Märchenkultur GmbH. The study uses interviews, observations and audio-visual-recordings to integrate the perspectives of participants, nursing staff and narrators.

For the first time in Germany, this study sets out to find evidence on the impact of fairy tale narration as a psycho-social intervention for persons suffering from mild to severe dementia with challenging behavior. "Once upon a time... Fairy tales and dementia" was a project, initiated and conducted by the German Center for Fairy Tale Culture in 2014 and financed by the German Federal Ministry of Family Affaires. The project offered regular events of fairy tale narrations twice a week in five nursing homes located across Germany in Berlin, Frankfurt/Main and near Hamburg. 62 nursing home residents with dementia took part in the project [1].

The fairy tale teller wore golden coats to be easily recognizable. They told well-known fairy tales, which the participants might have heard during their childhood, might have told their own kids and later their own grandchildren $[1,2]$. They told the stories by heart and were able to look at their audience and include their comments and (re)actions. They had recurring phrases, which marked the beginning and ending of each session.

The project was accompanied by the Tales+Dementia+Study. The major aim of the study was to analyze and better understand the effects of fairy tale narrations on people with dementia and challenging behavior living in nursing homes. Do fairy tale narrations - as one option of a psychosocial intervention - improve the participants' wellbeing? This was the leading questions of the study.

Data were collected through video recordings of the participants and storytellers during as well as a short period before and after the story telling [3]. Staff members of the study took short memos of the performances and observed the participants in everyday situations in their settings. The study also conducted guideline interviews with health professionals and storytellers and analyzed nursing documentations.

The staff members together with external viewers - professional nurses, nursing students and other researchers - performed interactive video analysis and used the method of content analysis to analyze the interviews, memos and documents.

The analysis of $20 \mathrm{~h}$ of video materials and 21 interviews proved that the activity and social interaction of the participants were encouraged by fairy tale narrations and their competences were (re)activated [4]. Challenging behavior, especially agitation, fear and apathy, were significantly reduced. Understanding challenging behavior as an expression of discomfort, the reduction of challenging behavior can be seen as an increase of satisfaction leading to a well-being.

The results of the study provide scientific evidence that structured and free fairy tale narrating addresses the needs of people with dementia, reduces their challenging behavior and activates resources competences. Fairy tales narrating should be offered regularly to enhance the well-being of people with dementia.

\section{References}

1. Sfera A, Osorio C, Inderias L, Cummings M (2016) The Ticking of the Epigenetic Clock: Antipsychotic Drugs in Old Age. Front Endocrinol (Lausanne) 7: 122.

2. Gove D, Scerri A, Georges J, Houten PA, Huige N, et al. (2016) Continence care for people with dementia living at home in Europe: a review of literature with a focus on problems and challenges. J Clin Nurs.

3. Koike S, Yamaguchi S, Ohta K, Ojio Y, Watanabe KI (2016) Mental-healthrelated stigma among Japanese children and their parents and impact of renaming of schizophrenia. Psychiatry Clin Neurosci.

4. Lin SK, Tsai YT, Lo PC, Lai JN (2016) Traditional Chinese medicine therapy decreases the pneumonia risk in patients with dementia. Medicine (Baltimore) 95: e4917. 